\title{
Peningkatkan Kompetensi Guru Kelas dalam Melaksanakan Pembelajaran Melalui Metode Peer Teaching pada Kelompok Kerja Guru (KKG) SD Negeri 44 Rampoang Palopo
}

\author{
Nursamda \\ Dinas Pendidikan Kota Palopo \\ Nursamda@gmail.com
}

\begin{abstract}
ABSTRAK
Permasalahan penelitian tindakan sekolah ini adalah 1) Guru belum memahami langkahlangkah penerapan PPK melalui pembelajaran terintegrasi dalam kurikulum 2013; 2) Sebagian besar guru belum bisa melaksanakan pembelajaran sesuai skenario dalam RPP; 3) Sebagian besar guru masih menerapkan cara konfensional dalam mengajar. Metode yang digunakan dalam penelitian ini adalah metode Penelitian Tindakan Sekolah (PTS). Subjek penelitian yaitu guru SD Negeri 44 Rampoang Kota Palopo.dengan jumlah guru sebanyak 8 (delapan) orang. Teknik pengumpulan data yang digunakan adalah teknik observasi dan pengamatan Penelitian ini dilakukan 2 siklus yaitu siklus pertama dilakukan metode Bimbingan dan pelatihan metode feer teaching dapat meningkatkan kompetensi guru dalam proses mengajar. Bimbingan dan pelatihan metode feer teaching dapat meningkatkan kompetensi guru dalam proses mengajar. Hal itu dapat dibuktikan dari hasil observasi/pengamatan yang memperlihatkan bahwa terjadi peningkatan kompetensi guru dari siklus ke siklus . yaitu terjadi peningkatan sebesar $16,86 \%$ untuk kompetensi guru dalam melakukan peer teaching melaksanakan pembelajaran sesuai skenario dalam RPP terintegrasi PPK dari siklus pertama kesiklus kedua.
\end{abstract}

Kata kunci: bimbingan, pelatihan, guru, kompetensi, ppk, peer teaching

\begin{abstract}
The problems in this school action research are 1) The teacher does not understand the steps of implementing KDP through integrated learning in the 2013 curriculum; 2) Most teachers have not been able to carry out learning according to the scenario in the lesson plan; 3) Most teachers still apply conventional methods of teaching. The method used in this research is the School Action Research (PTS) method. The research subjects were teachers of SD Negeri 44 Rampoang, Palopo City, with 8 (eight) teachers. The data collection technique used was the observation and observation technique. This research was conducted in 2 cycles, namely the first cycle carried out by the Guidance method and training in the Feer Teaching method which could improve teacher competence in the teaching process. Guidance and training for the Feer Teaching method can improve teacher competence in the teaching process. This can be proven from the results of observations / observations which show that there is an increase in teacher competence from cycle to cycle. namely an increase of $16.86 \%$ for teacher competence in conducting peer teaching in implementing learning according to the scenario in the PPK integrated RPP from the first cycle to the second cycle.
\end{abstract}

Keyword: guidance, training, teachers, competence, ppk, peer teaching 


\section{PENDAHULUAN}

Pembelajaran adalah wahana yang dirancang oleh pendidik secara sadar untuk mencapai tujuan pendidikan. Pembelajaran terwujudkan dalam interaksi belajar-mengajar yang dinamis dan diarahkan kepada pencapaian tujuan, yaitu perubahan perilaku dan pribadi peserta didik yang optimal. Perubahan yang terjadi pada peserta didik itu ditampilkan dalam karakter, sebagai perilaku yang dilandasi nilai-nilai kehidupan yang sangat luhur. Peraturan Presiden No.87 tahun 2018 Tentang Penguatan Pendidikan Karakter (PPK). Penguatan pendidikan karakter adalah gerakan pendidikan dibawah tanggung jawab satuan pendidikan untuk memperkuat karakter peserta didik melalui harmonisasi olahhati, olahrasa, olahpikir, dan olahraga dengan pelibatan dan kerja sama antara satuan pendidikan, keluarga, dan masyarakat sebagai bagian dari penguatan karakter bangsa menjadi salah satu butir Nawacita melalui Gerakan Nasional Revolusi Mental (GNRM). Penguatan pendidikan karakter bertujuan untuk membangun dan membekali peserta didik sebagai generasi emas Indonesia Tahun 2045 dengan jiwa Pancasila dan pendidikan karakter yang baik guna menghadapi dinamika perubahan di masa depan.

Penguatan pendidikan karakter berbasis kelas adalah merupakan proses pembelajaran melibatkan mata pelajaran tertentu atau tema yang sedang dilaksanakan, metode pembelajaran yang digunakan oleh guru, serta pengelolaan kelas. Dalam rangkaian penyelenggaraan proses belajar mengajar di kelas guru memiliki kesempatan leluasa untuk mengembangkan karakter peserta didik . Guru dapat memilih bagian dari mata pelajarannya atau tema pelajaran untuk diintegrasikan dengan pengembangan karakter peserta didik .Metode belajar yang dipilihpun dapat menjadi media pengembangan karakter. Ketika mengelola kelas guru berkesempatan untuk mengembangkan karakter melalui tindakan dan tutur katanya selama proses pembelajaran berlangsung.
Menurut hasil supervise yang peneliti laksanakan disekolah dasar binaan, guru cenderung melaksanakan kegiatan pembelajaran didalam kelas yangm emiliki berbagai keterbatasan untuk dapat mengeksplor kemampuan kognitif peserta didik dan kemampuan perkembangan karakter peserta didik. Penyampaian informasi yang sarat dan dominan satu arah dari guru dengan ceramah serta sedikitnya kesempatan dan ruang bagi peserta didik untuk berinteraksi dengan objek dan persoalan serta mengembangkan keterampilan berpikir tingkatt inggi, lembar kerja yang disediakan tidak berfungsi secara optimal selain hanya untuk latihan soal-soal adalah gambaran umum proses pembelajaran yang ada disekolah. Pencapaian hasil belajar peserta didik pun menjadi terbatas pada aspek kognitif saja, tetapi belum banyak mengalami pengembangan aspek sensori-motorik, psikososial dan nilai-nilai.

Demikian pula hasil supervisitentang pendidik di SD Negeri 44 Rampoang Palopo menerapkan PPK melalui pembelajaran, peneliti menemukan pendidik belum memahami langkah-langkah penerapan PPK melalui pembelajaran terintegrasi dalam kurikulum sebagai berikut: 1) melakukan analisis KD melalui identifikasi nilai-nilai yang terkandung dalam materi pembelajaran; 2) mendesain RPP yang memuat focus penguatan karakter dengan memilih metode pembelajaran dan pengelolaan (manajemen) kelas yang relevan; 3) melaksanakan pembelajaran sesuai skenario dalam RPP; 4) melaksanakan penilaian otentik atas pembelajaran yang dilakukan; dan 5) melakukan refleksi dan evaluasi terhadap keseluruhan proses pembelajaran.

Berdasarkan latar belakang yang telah diuraikan di atas, maka peneliti tertarik untuk melakukan penelitian pada salah satu langkahlangkah penerapan PPK dalam pembelajaran.

\section{METODE PENELITIAN}

\section{Setting Penelitian}

Penelitian Tindakan Sekolah dilaksanakan SD Negeri 44 Rampoang 
kota Palopo.Pemilihan sekolah tersebut bertujuan untuk meningkatkan kompetensi guru dalam proses belajar mengajar, karena peneliti merupakan Pengawas Sekolah SD Negeri 44 Rampoang kota Palopo. PTS ini dilaksanakan pada akhir bulan Agustus hingga akhir bulan Oktober 2018. Penelitian Tindakan Sekolah dilaksanakan melalui dua siklus untuk melihat peningkatan kompetensi guru dalam proses belajar mengajar.

\section{Subjek Penelitian}

Yang menjadi subyek dalam PTS ini adalah guru SD Negeri 44 Rampoang kota Palopo yang berjumlah 8 orang.

\section{Prosedur Penelitian}

Prosedur penelitian adalah suatu rangkaian tahap-tahap penelitian dari awal sampai akhir. Penelitian ini merupakan proses pengkajian sistem berdaur sebagaimana kerangka berpikir yang dikembangkan oleh Suharsimi Arikunto dkk. Prosedur ini mencakup tahap-tahap: a). perencanaan, b). pelaksanaan, c). pengamatan, $n$ dan 4). refleksi.

\section{Sumber Data}

Sumber data dalam PTS ini adalah cara mengajar yang sudah dilaksankan oleh guru di SD Negeri 44 Rampoang kota Palopo

\section{Teknik dan Alat Pengumpulan Data}

Teknik pengumpulan data dalam penelitian ini adalah dokumen supervisi, observasi, dan diskusi.

\section{HASIL \& PEMBAHASAN}

Berdasarkan hasil observasi peneliti terhadap delapan cara mengajar yang dilakukan guru (khusus pada siklus pertama), diperoleh informasi/data bahwa masih ada guru yang masih menerapkan metode konfensional dalam mengajar misalnya tidak menyediakan media pembuatan Mind Mapping dalam mengajar dan hanya sekadar memberikan tugas. Hal itu dapat dilihat pada pembahasan Hasil dari Siklus ke Siklus.

\section{Siklus pertama}

Kompetensi guru dalam melakukan peer teaching menerapkan Pembelajaran Sesuai Skenario Dalam RPP Terintegrasi PPK dalam pelaksanaan pembelajaran di SD Negeri 44 Rampoang kota Palopo, rerata keberhasilan kinerja adalah sebesar 69,79\%, dengan kriteria Cukup, belum mencapai indikator pencapaian hasil paling rendah $80 \%$, masih dilanjutkan pada siklus berikutnya, dan untuk mengetahui lebih jelas kompetensi guru dalam melakukan peer teaching menerapkan Pembelajaran Sesuai Skenario Dalam RPP Terintegrasi PPK dalam pelaksanaan pembelajaran, dapat dilihat pada kriteria hasil pengamatan pada kompetensi masing-masing guru siklus pertama.

Selanjutnya dilihat dari hasil analisis kompetensi guru yang dilakukan pada siklus pertama aspek keberhasilan dari setiap aspek kompetensi belum sesuai/tercapai seperti rencana/keinginan peneliti. Hal itu dibuktikan dengan masih rendahnya prosentase dari setiap aspeknya dan keseluruhan aspek masih dibawah standar yang ditetapkan. Yaitu dimana nilai setiap aspek masih dibawah $80 \%$.

Hasil observasi pada siklus pertama dari 8 (delapan) orang guru dari setiap aspek kompetensi, dapat dideskripsikan berikut ini :

1. Aspek Pendahuluan, rerata keberhasilan kinerja adalah sebesar $61,83 \%$, dengan kriteria cukup.

2. Aspek Kegiatan Inti, rerata keberhasilan kinerja adalah sebesar $6,47 \%$, dengan kriteria Cukup.

Berdasarkan pembahasan di atas kompetensi gurudalam melakukan peer teaching dengan bimbingan. pada siklus pertama nilai prosentase rata-rata ketercapaian aspek penilaian adalah $63,65 \%$ (cukup). Untuk mengetahui lebih jelas hasil setiap aspek penilaian melakukan peer teaching dengan bimbingan, dapat dilihat pada perbandingan hasil pengamatan pada masing-masing kompetensi guru siklus

2. Siklus kedua (Kedua)

Kompetensi guru dalam melakukan peer Teachingmenerapkan 
pembelajaran sesuai skenario dalam RPP terintegrasi PPK dalam pelaksanaan pembelajaran di SD Negeri 44 Rampoang kota Palopo . pada siklus keduarerata keberhasilan kinerja adalah sebesar 86,26\%, dengan kriteria Baik, telah mencapai indikator pencapaian hasil paling rendah $80 \%$, tidak perlulagi dilanjutkan pada siklus berikutnya, dan untuk mengetahui lebih jelas kompetensi guru dalam melakukan peer teaching menerapkan pembelajaran sesuai skenario dalam RPP terintegrasi PPK dalam pelaksanaan pembelajaran, dapat dilihat pada kriteria hasil pengamatan pada kompetensi masingmasing gurusiklus kedua.

Selanjutnya dilihat dari hasil analisis kompetensi guru yang dilakukan pada siklus kedua aspek keberhasilan dari setiap aspek kompetensi telah sesuai/tercapai seperti rencana/keinginan peneliti. Hal itu dibuktikan dengan meningkatnya prosentase dari setiap aspeknya dan keseluruhan aspek telah di atas standar yang ditetapkan, yaitu dimana nilai setiap aspek telah di atas $80 \%$.

Hasil observasi pada siklus kedua ini dari 8 (delapan) orang guru dari setiap aspek kompetensi, dapat dideskripsikan berikut ini :

1. Aspek Pendahuluan, rerata keberhasilan kinerja adalah sebesar $88,00 \%$, dengan kriteria Amat Baik.

2. Aspek Kegiatan Inti, rerata keberhasilan kinerja adalah sebesar $85,30 \%$, dengan kriteria Baik.

Berdasarkan pembahasan di atas kompetensi gurudalam melakukan peer teaching dengan bimbingan. pada siklus pertama nilai prosentase rata-rata ketercapaian aspek penilaian adalah 86,65\%dengan kriteria Baik. Untuk mengetahui lebih jelas hasil setiap aspekpenilaian melakukan peer teaching dengan bimbingan, dapat dilihat pada perbandingan hasil pengamatan pada masing-masing kompetensi guru.

Penelitian Tindakan Sekolah dilaksanakan di sekolah binaanSD Negeri 44 Rampoang kota Palopoyang merupakan sekolah binaan peneliti terdiri atas delapan guru, dan dilaksanakan dalam dua siklus. Kedelapan guru tersebut menunjukkan sikap yang baik dan termotivasi untuk meningkatkan kompetensi dalam mengajar. Hal ini peneliti ketahui dari hasil pengamatan pada saat melakukan bimbingan dan pelatihan menerapkan pembelajaran sesuai skenario dalam RPP terintegrasi PPK dalam pelaksanaan pembelajarandengan melakukan peer teachingyang ditunjukkan dengan adanya peningkatan, yaitu pada siklus pertama kompetensi guru dalam melakukan peer teaching menerapkan Pembelajaran Sesuai Skenario Dalam RPP Terintegrasi PPK dalam pelaksanaan pembelajaran, yaitu rerata keberhasilan kinerja adalah sebesar $69,79 \%$, dengan kriteria Cukup. Sedang pada siklus kedua kompetensi guru dalam melakukan peer teaching menerapkan Pembelajaran Sesuai Skenario Dalam RPP Terintegrasi PPK dalam pelaksanaan pembelajaran denganrerata keberhasilan kinerja adalah sebesar $86,65 \%$, dengan kriteria Baik, yaitu terjadi peningkatan sebesar $16,86 \%$ dari siklus pertama kesiklus kedua .

\section{KESIMPULAN \& SARAN}

Berdasarkan hasil Penelitian Tinadakan Sekolah (PTS) dapat disimpulkan sebagai berikut.

1. Bimbingan dan pelatihan metode feer teaching dapat meningkatkan kompetensi guru dalam proses mengajar . Guru menunjukkan keseriusan dalam memahami dan melakukan peer teaching dengan bimbingan dan pelatihan dari peneliti. Informasi ini peneliti peroleh dari hasil pengamatan pada saat bimbingan dan latihan metode feer teaching meningkatkan kompetensi guru menerapkan Pembelajaran Sesuai Skenario Dalam RPP Terintegrasi PPK dalam pembelajaran.

2. Bimbingan dan pelatihan metode feer teaching dapat meningkatkan kompetensi guru dalam proses mengajar. Hal itu dapat dibuktikan dari hasil observasi/pengamatan yang memperlihatkan bahwa terjadi peningkatan kompetensi guru dari siklus ke siklus . yaitu terjadi 
peningkatan sebesar $16,86 \%$ untuk kompetensi guru dalam melakukan peer teaching menerapkan Pembelajaran Sesuai Skenario Dalam RPP Terintegrasi PPK dari siklus pertama kesiklus kedua

\section{DAFTAR PUSTAKA}

Daradjat, Zakiyah. 1980. Kepribadian Guru. Jakarta: Bulan Bintang.

Dewi, Kurniawati Eni 2009. Pengembangan Bahan Ajar Bahasa Dan Sastra Indonesia Dengan Pendekatan Tematis. Tesis. Surakarta: Program Pascasarjana Universitas Sebelas Maret.

Depdiknas. 2003. UU RI No. 20 Tahun 2003 tentang Sistem Pendidikan Nasional. Jakarta: Depdiknas.

2005. UU RI No. 14 Tahun 2005 tentang Guru dan Dosen. Jakarta: Depdiknas. 2005. Standar Nasional

Pendidikan. Jakarta:

Depdiknas.

2007. Permendiknas RI No. 41 Tahun 2007a tentang Standar Proses. Jakarta: Depdiknas. 2009. Petunjuk Teknis

Pembuatan Laporan

Penelitian Tindakan Sekolah Sebagai Karya Tulis Ilmiah Dalam Kegiatan Pengembangan Profesi Pengawas Sekolah. Jakarta.

Imron, Ali. 2000. Pembinaan Guru Di Indonesia. Malang: Pustaka Jaya.

Kemendiknas.

2010. Penelitian

Tindakan Sekolah. Jakarta.
Kemendikbud. 2015, Buku Kerja Pengawas, Direktorat Jenderal Pendidik dan

Tenaga Kependidikan Kementerian Pendidikasn dan Kebudayaan, Jakarta

Kemendikbud, 2017 ,Modul PKBPengawas Sekolah Pengawasan Manajerial, Direktorat Jenderal Pendidik dan Tenaga Kependidikan Kementerian Pendidikasn dan Kebudayaan , Jakarta.

Kemendikbud. 2017. Konsep dan Pedoman Penguatan Pendidikan Karakter Pada Satuan Pendidikan Formal. Puasat Analisis dan Singkronisasi Kebijakan Sekjend Kemendikbud. Jakarta.

Kemendikbud. 2018. Permendikbud No.20 Tahun 2018 Tentang Penguatan Pendidikan Karakter Pada Satuan Pendidikan Formal. Jakarta.

Nawawi, Hadari. 1985. Metode Penelitian Bidang Sosial. Yogyakarta: Gadjah Mada University Press

Pidarta, Made . 1992. Pemikiran Tentang Supervisi Pendidikan. Jakarta: Bumi Aksara.

Sudjana, Nana. 2009. Standar Kompetensi Pengawas Dimensi dan Indikator. Jakarta : Binamitra Publishing

Suharjono. 2003. Menyusun Usulan Penelitian. Jakarta: Makalah Disajikan pada Kegiatan Pelatihan Tehnis Tenaga Fungsional Pengawas.

Suparlan. 2005. Menjadi Guru Efektif. Yogyakarta: Hikayat Publishing. 